\title{
HUBUNGAN KEWENANGAN ANTARA MAHKAMAH AGUNG DAN KOMISI YUDISIAL TERHADAP PENGAWASAN ETIKA HAKIM DALAM PERSPEKTIF HUKUM ISLAM
}

\author{
Wahyu Ningsih \\ Institut Agama Islam Negeri Bengkulu \\ Jalan Raden Fatah Kota Bengkulu \\ Email: wahyuningsih05071995@gmail.com \\ Rohmadi \\ Institut Agama Islam Negeri Bengkulu \\ Jalan Raden Fatah Kota Bengkulu \\ Email: rohmadi.rohmadi@gmail.com \\ Masril \\ Institut Agama Islam Negeri Bengkulu \\ Jalan Raden Fatah Kota Bengkulu \\ Email: masril@gmail.com
}

\begin{abstract}
Oversight carried out by the Supreme Court and Judicial Commission will be very closely related to the independence of judges in deciding a case. The authority of the Supreme Court and the Judicial Commission in terms of ethical oversight of judges is intended to maintain and uphold the honor, dignity, and behavior of judges. From the results of the study found that the relationship between the authority of the Supreme Court and the Judicial Commission on the ethical supervision of judges must not exceed the authority regulated by the Act. The authority of the Supreme Court in following up the judicial ethics oversight report by the Judicial Commission, namely if the Supreme Court considers it appropriate or not, the Supreme Court notifies the Judicial Commission. In Islamic law supervision is carried out structurally operationally by the judicial institution Qadi al-Qudat and spiritually by Allah SWT.
\end{abstract}

Keywords: Oversight; Authority; Supreme Court; Judicial Commission; Judge.

\begin{abstract}
Abstrak: Pengawasan yang dilakukan oleh Mahkamah Agung dan Komisi Yudisial akan sangat erat kaitannya dengan independensi hakim dalam memutus suatu perkara. Adanya kewenangan Mahkamah Agung dan Komisi Yudisial dalam hal pengawasan etika hakim dimaksudkan untuk menjaga dan menegakkan kehormatan, keluhuran martabat, serta perilaku hakim. Dari hasil penelitian ditemukan hubungan kewenangan antara Mahkamah Agung dan Komisi Yudisial terhadap pengawasan etika hakim tidak boleh melampaui kewenangan yang diatur oleh Undang-undang. Kewenangan Mahkamah Agung dalam menindaklanjuti laporan pengawasan etika hakim oleh Komisi Yudisial yaitu jika Mahkamah Agung menimbang layak atau tidak maka Mahkamah Agung memberitahu Komisi Yudisial. Dalam hukum Islam pengawasan dilakukan secara struktural operasional oleh lembaga peradilan Qadi al-Qudat dan secara spiritual oleh Allah SWT.
\end{abstract}

Kata Kunci: Pengawasan; Kewenangan; Mahkamah Agung; Komisi Yudisial; Hakim. 
AL-IMARAH: Jurnal Pemerintahan dan Politik Islam

Vol. 4, No. 2, 2019

\section{Pendahuluan}

Perubahan Undang-undang Dasar Negara Republik Indonesia Tahun 1945 telah membawa perubahan dalam kehidupan ketatanegaraan khususnya dalam pelaksanaan kekuasaan kehakiman. Sesuai dengan ketentuan Undang-undang Republik Indonesia Nomor 48 Tahun 2009 tentang Kekuasaan Kehakiman Pasal 18, Negara berdasarkan atas hukum maka salah satu prinsip penting Negara hukum adalah jaminan penyelenggaraan kekuasaan kehakiman yang merdeka, bebas dari pengaruh kekuasaan lainnya untuk menyelenggarakan peradilam guna menegakkan hukum dan keadilan. ${ }^{1}$

Negara merupakan satu kesatuan yang memiliki tujuan untuk mencapai kebaikan yang tertinggi, dimana kesempurnaan manusia sebagai bagian dari Negara. Sehingga dapat digarisbawahi bahwa Negara memiliki tanggung jawab penuh dalam menjamin kehidupan warga Negara sebagai sebuah komponen pembentuk Negara itu sendiri. $^{2}$

Kekuasaan kehakiman dilakukan oleh sebuah Mahkamah Agung dan badan peradilan yang berada dibawahnya dalam lingkungan peradilan umum, lingkungan peradilan agama, lingkungan peradilan militer,

1 Ni'matul Huda, Hukum Tata Negara Indonesia, (Jakarta: PT Raja Grafindo Persada), h. 205206.

2 Muhammad Syahwalan, "Kebijakan Politik Keuangan Terhadap Pembangunan Negara dalam Sistem Ketatanegaraan Islam", Jurnal Al-Imarah Vol 4, No. 1, 2019, h. 12. lingkungan peradilan tata usaha Negara, dan oleh sebuah Mahkamah Konstitusi.

Menurut Wirdjono Prodjodikora di Indonesia Mahkamah Agung adalah badan peradilan yang tertinggi yang bersendi atas Undang-undang Dasar melakukan pengawasan tertinggi atas perbuatan pengadilan yang lain. Dalam pengawasan ini dan ada lagi dalam peradilan kasasi sudah seharusnyalah Mahkamah Agung dengan keputusankeputusannya mempengaruhi cara berjalannya peradilan di seluruh Indonesia. ${ }^{3}$

Agar lebih menguatkan Mahkamah Agung serta memaksimalkan fungsi dan peran Mahkamah Agung sebagai lembaga pemegang kekuasaan tertinggi di bidang hukum, maka ketetapan MPR RI No. X/MPR/1998 tentang Pokok Reformasi Pembangunan dalam rangka penyelamatan dan normalisasi kehidupan nasional, berfungsi sebagai haluan negara antara lain menegaskan bahwa pelaksanaan reformasi di bidang hukum dengan agenda yang harus dijalankan, yaitu pemisahan yang tegas antara fungsi yudikatif dan eksekutif. ${ }^{4}$

Kalangan pemerhati hukum dan organisasi nonpemerintah menganggap perlu dibentuk Komisi Yudisial. Komisi ini nantinya diharapkan dapat memainkan fungsi-fungsi tertentu dalam sistem yang baru, khususnya rekrutmen hakim agung dan pengawasan

\footnotetext{
${ }^{3}$ Masril dan Ade Kosasih, "Keberlakuan Asas Ne Bis Idem terhadap Putusan Pengadilan Adat dalam Tata Hukum Indonesia", Jurnal Al-Imarah Vol 4, No. 1, 2019, h. 53.

${ }^{4}$ Wildan Sayuthi Mustofa, Kode Etik Hakim Edisi Kedua, (Jakarta: Kencana, 2013), h. 93.
} 
terhadap hakim. Banyak pakar mengatakan, bahkan putusan Mahkamah Konstitusi juga menyebutkan, bahwa Komisi Yudisial (KY) adalah lembaga penunjang atau pembantu dalam pelaksanaan kekuasaan kehakiman.

Dari sudut materi tugas yang dibebankan, KY memang merupakan lembaga yang membantu dalam pelaksanaan tugas kekuasaan kehakiman, tetapi sebagai lembaga Negara yang menjadi "pengawas eksternal" KY sebenarnya adalah lembaga Negara yang mandiri seperti yang secara eksplisit disebutkan di dalam Pasal 24B ayat (1) UU tentang Komisi Yudisial, yakni UU Nomor 22 Tahun 2004 dibentuk pada tahun 2004, sedangkan Komisi Yudisial sendiri baru dibentuk pada pertengahan tahun 2005.

Sesuai dengan Undang-Undang Republik Indonesia Nomor 3 Tahun 2009 tentang Perubahan Kedua atas Undang-undang Nomor 14 Tahun 1985 tentang Mahkamah Agung Pasal 32A ayat (1-3), di samping pengawasan internal oleh Mahkamah Agung terhadap hakim, pengawasan eksternal dilakukan oleh Komisi Yudisial yang berpedoman kepada kode etik dan pedoman perilaku hakim. Kode etik dan pedoman perilaku hakim ditetapkan oleh Komisi Yudisial dan Mahkamah Agung.

Hakim sebagai aktor utama atau figur sentral dalam proses peradilan senantiasa dituntut untuk mengasah kepekaan nurani, memelihara integritas, kecerdasan moral, dan meningkatkan profesionalisme dalam menegakkan hukum dan keadilan bagi masyarakat banyak. ${ }^{5}$

Wewenang dan tugas hakim yang sangat besar itu menuntut tanggung jawab yang tinggi, sehingga putusan pengadilan yang diucapkan dengan kepala putusan "Demi keadilan berdasarkan Ketuhanan Yang Maha Esa" menunjukkan kewajiban menegakkan hukum, kebenaran dan keadilan itu wajib dipertanggungjawabkan secara horizontal kepada semua manusia, dan secara vertikal dipertanggungjawabkan kepada Tuhan Yang Maha Esa. ${ }^{6}$ Bahkan putusan Peradilan Agama ditambah kalimat:

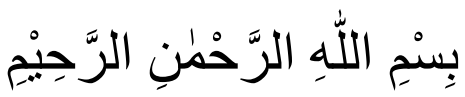

Artinya: "Dengan nama Allah yang Maha Pengasih, Maha Penyayang”.

Banyak dalil-dalil Al-Qur'an maupun hadits yang memberi peringatan kepada manusia bahwa semua perbuatan dan tingkah lakunya diawasi oleh Tuhan. Berikut ini beberapa ayat Al-Qur'an yang mengandung pesan pengawasan terhadap manusia termasuk hakim di dalamnya: ${ }^{7}$

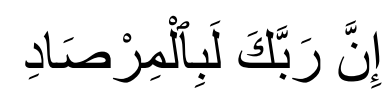

Artinya: "Sungguh, Tuhanmu benarbenar mengawasi” (QS. Al-Fajr [89]: 14).

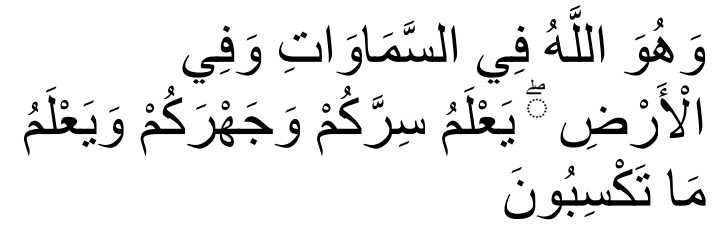

${ }^{5}$ Wildan Sayuthi Mustofa, ... h. 118.

${ }^{6}$ Wildan Sayuthi Mustofa, ... h. 118.

${ }^{7}$ Wildan Sayuthi Mustofa, ... h. 267-268. 
AL-IMARAH: Jurnal Pemerintahan dan Politik Islam Vol. 4, No. 2, 2019

Artinya: "Dan Dialah Allah (Yang disembah), di langit maupun di bumi; Dia mengetahui apa yang kamu rahasiakan dan apa yang kamu nyatakan dan mengetahui (pula) apa yang kamu kerjakan” (QS. Al-An'am [6]: 3).

Untuk mewujudkan suatu pengadilan sebagaimana diatas, perlu terus diupayakan secara maksimal tugas pengawasan secara internal dan eksternal oleh Mahkamah Agung Republik Indonesia dan Komisi Yudisial Republik Indonesia. Wewenang dan tugas pengawasan tersebut diorientasikan untuk memastikan bahwa semua hakim sebagai pelaksana utama dari fungsi pengadilan itu berintegritas tinggi, jujur, dan profesional, sehingga memperoleh kepercayaan dari masyarakat pencari keadilan.

Oleh karena itu, adanya pengawasan yang dilakukan oleh Mahkamah Agung dan Komisi Yudisial akan sangat erat hubungannya dikaitkan dengan independensi hakim dalam memutus suatu perkara.

\section{Pembahasan}

\section{Kode Etik Hakim di Indonesia}

Hakim mempunyai tugas luhur menegakkan hukum dan keadilan atas dasar kebenaran dan kejujuran yang bertanggung jawab kepada Tuhan Yang Maha Esa. Hakim harus memiliki sifat dan sikap yang dapat menjamin terlaksananya tugas tersebut dengan sebaik-baiknya, yang sesuai dengan apa yang menjadi pandangan hidup dan falsafah Negara serta kepribadian bangsa Indonesia. ${ }^{8}$
Kode etik hakim yang dijadikan acuan saat ini adalah berdasarkan hasil Munas IKAHI ke-13, tanggal 30 Maret 2001 di Bandung. Adapun sifat-sifat yang harus dimiliki hakim disublimasikan, digambarkan dalam lambang menjadi PANCA DARMA HAKIM, yakni: ${ }^{9}$

1. Kartika : Ketuhanan Yang Maha Esa.

\begin{tabular}{|c|c|c|}
\hline 2. Cakra & : Adil. & \\
\hline 3. Candra & $\begin{array}{l}\text { Bijaksana } \\
\text { Berwibawa. }\end{array}$ & Atau \\
\hline 4. Sari & $\begin{array}{l}\text { Budi Luhur } \\
\text { Berkelakuan } \\
\text { Tercela. }\end{array}$ & $\begin{array}{r}\text { Atau } \\
\text { Tidak }\end{array}$ \\
\hline 5. Tirta & $\begin{array}{l}\text { Seseorang } \\
\text { Harus Jujur. }\end{array}$ & Hakim \\
\hline
\end{tabular}

2. Kewenangan Mahkamah Agung dan Komisi Yudisial dalam Pengawasan Kode Etik Hakim

a. Kewenangan MA dalam Pengawasan Kode Etik Hakim

Pengawasan MA kepada jajaran MA sendiri dan peradilan dibawahnya ditangani oleh Badan Pengawasan (Bawas). Bawas kemudian juga mempunyai tugas memantau, memeriksa, dan meneliti serta mengawasi kinerja MA dan badan peradilan dibawahnya. Bawas melaksanakan tugas MA dalam pengawasan tertinggi berdasarkan 
Wahyu Ningsih, Rohmadi, dan Masril:

Hubungan Kewenangan Antara Mahkamah Agung Dan Komisi Yudisial Terhadap Pengawasan Etika Hakim dalam Perspektif Hukum Islam

undang-undang yang mangawasi tingkah laku dan perbuatan para hakim dan aparat peradilan dalam menjalani tugas peradilan. ${ }^{10}$

Adapun kewenangan Badan Pengawas MA adalah, (1) melakukan pengawasan rutin atau reguler, keuangan dan penanganan pengaduan masyarakat, (2) melakukan review keuangan terhadap satuan kerja yang ada pada MA dan badan peradilan dibawahnya, (3) pengawasan lainnya yang ditugaskan oleh pimpinan MA.

\section{b. Kewenangan KY dalam}

\section{Pengawasan Kode Etik Hakim}

Komisi Yudisial secara eksplisit dinyatakan sebagai lembaga pengawas eksternal perilaku hakim dalam Pasal 13D ayat (2) UU Nomor 49 Tahun 2009 tentang Peradilan Umum, dan Pasal 13D ayat (2) UU Nomor 51 Tahun 2009 tentang Peradilan Tata Usaha Negara yang memberikan wewenang kepada KY untuk: ${ }^{11}$

1) Menerima dan menindaklanjuti pengaduan masyarakat dan/atau informasi tentang dugaan pelanggaran Kode Etik dan/atau Pedoman Perilaku Hakim;

10 Rencana Strategi Badan Pengawasan Mahkamah Agung Tahun 2011.

11 Imam Anshori Saleh, Konsep Pengawasan Kehakiman, (Malang: Setara Press, 2014), h. 147.
2) Memeriksa dan memutus dugaan pelanggaran atas Kode Etik dan/atau Pedoman Perilaku Hakim;

3) Dapat menghadiri persidangan di pengadilan;

4) Menerima dan menindaklanjuti pengaduan Mahkamah Agung dan badan-badan peradilan dibawah Mahkamah Agung atas dugaan pelanggaran Kode Etik dan/atau Pedoman Perilaku Hakim;

5) Melakukan verifikasi terhadap pengaduan;

6) Meminta keterangan atau data kepada Mahkamah Agung dan/atau pengadilan;

7) Melakukan pemanggilan dan meminta keterangan dari hakim yang diduga melanggar Kode Etik dan/atau Pedoman Perilaku Hakim untuk kepentingan pemeriksaan;

8) Menetapkan dalam keputusan berdasarkan hasil pemeriksaan.

Komisi Yudisial sesuai Undang-Undang Nomor 18 Tahun 2011 tentang Perubahan Atas Undang-Undang Nomor 22 Tahun 2004 Tentang Komisi Yudisial Pasal 13, mempunyai empat wewenang, yakni: 
1) Mengusulkan pengangkatan hakim agung dan hakim ad hoc di MA kepada DPR untuk mendapatkan persetujuan;

2) Menjaga dan menegakkan kehormatan, keluhuran serta perilaku hakim;

3) Menetapkan Kode Etik dan/atau Pedoman Perilaku Hakim bersama-sama dengan MA; serta

4) Menjaga dan menegakkan pelaksanaan Kode Etik dan/atau Pedoman Perilaku Hakim.

\section{c. Garis Batas Teknis Yudisial dan}

\section{Perilaku Hakim}

KY mengadakan simposium internasional dengan topik The Line Between Legal Error and Misconduct of Judges. Hasil simposium tersebut, ditemukan adanya tiga hal yang bisa menjadi garis batas teknis yudisial dan pelanggaran perilaku. Ketiga hal tersebut adalah sebagai berikut: ${ }^{12}$

1) Kesalahan fatal (egregious legal errors)

Yang dimaksud fatal disini adalah hakim mengabaikan hak-hak konstitusional para pihak dalam putusannya.

2) Pola pelanggaran yang dilakukan oleh hakim (pelanggaran yang dilakukan secara berulang,

${ }^{12}$ Majalah Komisi Yudisial, Hakim dan Media Sosial, (Edisi Juli-September 2017), h. 41. "pattern or practice of legas errors").

Seorang hakim yang telah terbukti melakukan beberapa kali pelanggaran legal error yang berbeda. Contohnya, Hakim Fuselier yang telah melakukan tiga jenis pelanggaran legal error, yaitu abuse of the contempt power, bersidang tanpa kehadiran penuntut umum, dan melakukan prosedur yang tidak memenuhi ketentuan undang-undang.

3) Perilaku buruk (bad faith)

Hakim yang mempunyai perilaku buruk karena melakukan tindakan korup dalam melaksanakan tugasnya.

\section{Hubungan Kewenangan Mahkamah} Agung dan Kimisi Yudisial terhadap Pengawasan Etika Hakim

Mahkamah Agung dalam hal mengawasi tingkah laku dan perbuatan para hakim dalam menjalankan tugasnya tentunya tidak boleh mengurangi kebebasan Hakim dalam artian Mahkamah Agung dalam melakukan pengawasannya tidak boleh menimbulkan akibat seorang hakim tidak independen dalam memeriksa dan memutus suatu perkara yang ditanganinya, dikarenakan dalam hal memeriksa dan memutus perkara di dalam KUHAP terdapat esensi pengawasan terhadap pelaksanaan proses peradilan 
Wahyu Ningsih, Rohmadi, dan Masril: Hubungan Kewenangan Antara Mahkamah Agung Dan Komisi Yudisial Terhadap Pengawasan Etika Hakim dalam Perspektif Hukum Islam

dalam menangani suatu perkara seperti adanya upaya hukum biasa (Bab XVII KUHAP) maupun upaya hukum luar biasa (Bab XVIII KUHAP).

Hubungannya pengawasan yang dilakukan oleh Komisi Yudisial menurut Undang-Undang Nomor 22 Tahun 2004 tentang Komisi Yudisial Pasal 21:

"Komisi Yudisial bertugas mengawasi perilaku hakim dalam rangka menegakkan kehormatan dan keluhuran martabat serta menjaga perilaku hakim. Singkatnya, untuk menegakkan kehormatan dan keluhuran martabat serta menjaga perilaku hakim, Komisi Yudisial memliki kewenangan melakukan pengawasan terhadap perilaku hakim dan pengajuan usulan penjatuhan sanksi terhadap hakim, dan pengusulan penghargaan kepada hakim atas prestrasi dan jasannya".

Komisi Yudisial mengawasi agar perilaku hakim menjadi baik, sehingga dapat menjadi simbol mengenai pentingnya infra struktur sistem etika perilaku dalam sistem ketatanegaraan menurut UUD 1945. Komisi Yudisial sebagai salah satu lembaga negara yang bersifat penunjang (auxiliary organ) terhadap lembaga kekuasaan kehakiman sesuai dengan Pasal 24 ayat (2) UUD 1945.

\section{a. MA bekerja sana dengan KY}

1) Majelis Kehormatan Hakim $(\mathrm{MKH})$

Berdasarkan Nota Kesepahaman atau kerjasama antara MA RI dengan KY tanggal 8 April 2009 tentang Kode Etik dan Pedoman Perilaku Hakim No: 047/KMA/SKB/IV/2009 02/SKB/P.KY/IV/2009 MA dan KY telah melakukan pemeriksaan bersama dan membentuk Majelis Kehormatan Hakim.

2) Pembentukan Tim Penghubung dan Tim Asistensi

Untuk meningkatkan koordinasi pelaksanaan fungsi pengawasan bagi aparat peradilan, diperlukan suatu upaya untuk mensinergikan kegiatan pengawasan baik yang bersifat internal maupun eksternal. Untuk itu MA telah membentuk Tim Penghubung dan Tim Asistensi berdasarkan Surat Keputusan Ketua MA: ${ }^{13}$

a) Surat Keputusan Ketua Mahkamah Agung RI No: 211/KMA/SK/XII/2011 tentang Pembentukan Tim Penghubung MA RI dalam Rangka Kerjasama MA RI dan KY RI.
13 Surat Keputusan Ketua Mahkamah Agung RI No: 211/KMA/SK/XII/2011. 
b) Surat Keputusan Ketua Mahkamah Agung RI No: 211/KMA/SK/XII/2011 tentang Pembentukan Tim Asistensi atas Tim Penghubung MA RI dalam Kerangka Kerjasama MA RI dan KY RI. Tim Penghubung dibentuk untuk keperluan komunikasi dan koordinasi sedangkan Tim Asistensi untuk membantu merumuskan Peraturan Teknis terkait.

b. Keputusan Bersama MA dan KY tentang KEPPH

Pada tanggal 8 April 2009, Ketua MA dan Ketua KY menandatangani Keputusan Bersama nomor $\quad$ 047/KMA/SKB/IV/2009 tentang Kode Etik dan Pedoman Perilaku Hakim (KE-PPH). Prinsip dasar KEPPH diimplementasikan dalam 10 (sepuluh) aturan perilaku sebagai berikut: (1) Berperilaku Adil, (2) Berperilaku Jujur, (3) Berperilaku Arif dan Bijaksana, (4) Bersikap Mandiri, (5) Berintegritas Tinggi, (6) Bertanggung Jawab, (7) Menjunjung Tinggi Harga Diri, (8) Berdisiplin Tinggi, (9) Berperilaku Rendah Hati, (10) Bersikap Profesional. ${ }^{14}$

${ }^{14}$ Keputusan Bersama Ketua MA RI dan Ketua KY RI Nomor: 047/KMA/SKB/IV/2009 02/SKB/P.KY/IV/2009 tentang Kode Etik dan Pedoman Perilaku Hakim.
4. Kewenangan Mahkamah Agung dalam Menindaklanjuti Laporan Pengawasan Etika Hakim oleh Komisi Yudisial

Penanganan pengaduan dugaan pelanggaran kode etik oleh hakim, kedua lembaga telah mengeluarkan Peraturan Bersama Mahkamah Agung dan Komisi Yudisial Nomor 02/PB/MA/IX/2012 02/PB/P.KY/09/2012 tentang Panduan Penegakan Kode Etika dan Pedoman Perilaku Hakim (Peraturan Bersama Kode Etik Hakim). Dalam peraturan itu, terdapat klausul pemeriksaan bersama dilakukan dalam hal terjadi perbedaan pendapat antara KY dan MA mengenai usulan KY tentang hasil pemeriksaan atau penjatuhan sanksi selain sanksi pemberhentian dengan hormat dan pemberhentian tidak hormat. ${ }^{15}$

Selain itu, pemeriksaan bersama MA-KY juga diperuntukan salah satunya terhadap laporan yang menarik perhatian publik dan masing-masing lembaga memandang perlu untuk melakukan pemeriksaan bersama. Terhadap hasil pemeriksaan yang menyatakan terdapat pelanggaran Kode Etik dan Pedoman Perilaku Hakim (KEPPH), KY bisa mengusulkan sanksi kepada MA. Selain langsung ke MA, laporan dugaan kode etik bisa diadukan kepada KY. ${ }^{16}$

\begin{tabular}{|c|c|c|}
\hline 15 & Peraturan & Bersama \\
\hline \multicolumn{3}{|c|}{ 02/PB/MA/IX/2012 - 02/PB/P.KY/09/2012. } \\
\hline 16 & Peraturan & Bersama \\
\hline
\end{tabular}


Kemudian, KY mengusulkan ke MA untuk menindaklanjuti laporan tersebut. Jika MA menimbang layak, maka dalam waktu 60 hari sejak hasil telaah diterima, MA memberitahukan hasilnya ke KY. Sementara, jika tidak layak ditindaklanjuti, dalam waktu 30 hari sejak hasil telaah diterima MA wajib memberitahukan ke KY. ${ }^{17}$

\section{Pengawasan Etika Hakim dalam}

\section{Perspektif Hukum Islam}

Pengawasan yang mempunyai karakteristik antara lain: pengawasan bersifat material dan spiritual, monitoring bukan hanya oleh pengawas hakim, tetapi juga Allah SWT, menggunakan metode yang manusiawi yang menjunjung martabat manusia. Dengan karakteristik tersebut dapat dipahami bahwa perilaku dalam menjalankan tugasnya sebagai pemutus sengketa akan bertanggung jawab kepada pengawas baik internal, Mahkamah Agung, dan eksternal, Komisi Yudisial serta Allah SWT sebagai pengawas yang Maha Mengetahui. ${ }^{18}$

Di sisi lain, pengawasan dalam konsep Islam lebih mengutamakan menggunakan pendekatan manusiawi,

\footnotetext{
${ }^{17}$ https://m.hukumonline.com/berita/baca/it56e 28289869fd/mau-laporkan-hakim-yuk-simakprosedurnya/, diakses tanggal 1 April 2019 Pukul 01.17 WIB.

18 R Mida Hayati, "BAB II Kajian Pustaka (Tanpa Judul)”, http://repository.radenintan.ac.id/75/7/BAB_II.pdf, diakses pada Minggu 5 Mei 2019 pukul 02.37 WIB.
}

pendekatan yang dijiwai oleh nilai-nilai keislaman.

Terdapat beberapa ayat yang menjelaskan tentang pengawasan antara lain dalam surat As-Sajdah, ayat 5 berikut:

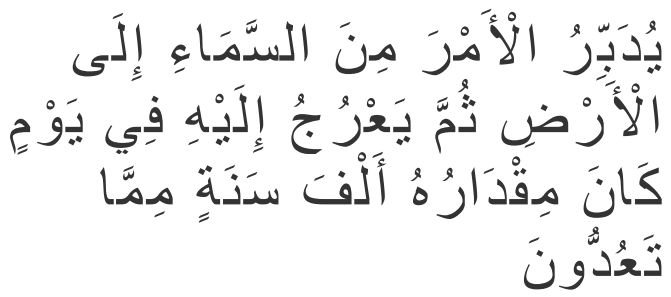

Artinya: "Dia mengatur segala urusan dari langit ke bumi, kemudian (urusan) itu naik kepada-Nya dalam satu hari yang kadarnya (lamanya) adalah seribu tahun menurut perhitunganmu”. (QS. As-Sajdah [32]: 5).

Kandungan ayat diatas menjelaskan bahwa Allah SWT adalah pengatur alam. Keteraturan alam raya ini, merupakan bukti kebesaran Allah SWT dalam mengelola alam ini. Namun, karena manusia yang diciptakan Allah SWT telah dijadikan sebagai khalifah di bumi, maka dia harus mengatur dan mengelola bumi dengan sebaik-baiknya sebagaimana Allah SWT mengatur alam raya ini.

Pengawasan atau Al-Muraqabah dalam pandangan Islam dilakukan untuk meluruskan yang tidak lurus, mengoreksi yang salah, dan membenarkan yang hak. Pengawasan dalam Islam terbagi menjadi dua hal, yaitu: ${ }^{19}$ Pertama, kontrol yang berasal dari diri sendiri yang bersumber

${ }^{19}$ Said, "Fungsi Pengawasan dalam Islam", http://said-iqbal.blogspot.com/2012/01/fungsipengawasan-dalam-islam.html, diakses pada Rabu 15 Mei 2019 Pukul 04.16 WIB. 
AL-IMARAH: Jurnal Pemerintahan dan Politik Islam Vol. 4, No. 2, 2019

dari tauhid dan keimanan kepada Allah SWT.

Kemudian juga harus didasari atas ketakwaan yang tinggi kepada Allah, dimana dengan adanya ketakwaan kepada Allah, maka akan ada rasa takut untuk melakukan suatu kecurangan dalam pekerjaan dan merasa diri bahwa Allah selalu melihat apa yang kita perbuat. Kedua, sebuah pengawasan akan lebih efektif jika sistem pengawasan tersebut dilakukan dari luar diri sendiri. Sistem pengawasan ini dapat terdiri atas mekanisme pengawasan dari pemimpin yang berkaitan dengan penyelesaian tugas yang telah didelegasikan, kesesuaian antara penyelesaian tugas dan perencanaan tugas, dan lain-lain sebagainya.

Pengawasan hakim menurut fiqh siyasah dalam hal pembagian kekuasaan, ialah pengawasan yang berada dalam lingkup kekuasaan al-sultah al-qada'iyyah atau lembaga kekuasaan yudikatif, di dalamnya terdapat suatu lembaga yang bernama Qadi al-Qudat. Diberikan wewenang dalam hal mengawasi hakim, terutama hakim-hakim yang berada di bawahnya dengan kewenangan ini dapat juga dikatakan sebagai Ketua Mahkamah Agung dalam praktek ketatanegaraan di Indonesia. Terlepas dari itu, juga dapat disebut Komisi Yudisial secara khusus dalam hal kewenangan mengawasi hakim. Karena, lembaga ini di Indonesia merupakan lembaga yang mempunyai kewenangan mengusulkan pengangkatan hakim agung, mempunyai wewenang lain dalam menjaga dan menegakkan kehormatan, keluhuran martabat, serta perilaku hakim (pengawasan terhadap hakim).

Selain mengawasi Qadi al-Qudat juga diberikan kewenangan untuk mengangkat dan memberhentikan qadiqadi, membatalkan putusan qadi, dan mengawasi terhadap fatwa. Jika demikian artinya tidak ada secara khusus dalam fiqh siyasah menyebutkan mengenai lembaga pengawas seperti halnya di dalam praktek ketatanegaraan di Indonesia yang terdapat lembaga khusus yaitu Komisi Yudisial. Akan tetapi, kewenangan Qadi al-Qudat dalam mengawasi hakim itu juga bersifat fungsional dalam lembaga tersebut.

\section{Penutup}

Hubungan pengawasan yang dilakukan oleh Mahkamah Agung dan Komisi Yudisial terhadap prilaku hakim tidak boleh melampaui kewenangan yang diatur oleh undang-undang. Dengan adanya pengawasan yang dilakukan oleh Mahkamah Agung dan Komisi Yudisial yang dilakukan terhadap hakim sebagai kontrol bagi hakim dalam menunjang tegaknya kehormatan, keluhuran martabat, dan perilaku hakim sebagai pejabat penegak hukum sehingga terciptanya prilaku hakim sebagai prilaku hukum yang akhirnya tercapainya tujuan hukum yaitu keadilan, kepastian dan 
kemanfaatan hukum
diamanatkan oleh UUD 1945. Adapun
pengawasan tersebut dalam perspektif Islam

mempunyai karakteristik antara lain: pengawasan bersifat material dan spiritual, monitoring bukan hanya oleh pengawas hakim, tetapi juga Allah SWT, menggunakan metode yang manusiawi yang menjunjung martabat manusia. Dengan karakteristik tersebut dapat dipahami bahwa perilaku dalam menjalankan tugasnya sebagai pemutus sengketa akan bertanggung jawab kepada pengawas baik internal, Mahkamah Agung, dan eksternal, Komisi Yudisial serta Allah SWT sebagai pengawas yang Maha Mengetahui. Di sisi lain, pengawasan dalam konsep Islam lebih mengutamakan menggunakan pendekatan manusiawi, pendekatan yang dijiwai oleh nilai-nilai keislaman.

\section{Pustaka Acuan}

Imam Anshori Saleh, Konsep Pengawasan Kehakiman, (Malang: Setara Press, 2014).

Keputusan Bersama Ketua MA RI dan Ketua KY RI Nomor: 047/KMA/SKB/IV/2009 02/SKB/P.KY/IV/2009 tentang Kode Etik dan Pedoman Perilaku Hakim.

Majalah Komisi Yudisial, Hakim dan Media Sosial, (Edisi Juli-September 2017).

Muhammad Syahwalan, "Kebijakan Politik Keuangan Terhadap Pembangunan Negara dalam Sistem Ketatanegaraan Islam", Jurnal Al-Imarah Vol 4, No. 1,2019
Ni'matul Huda, Hukum Tata Negara Indonesia, (Jakarta: PT Raja Grafindo Persada).

Peraturan Bersama nomor 02/PB/MA/IX/2012 - 02/PB/P.KY/09/2012.

Rencana Strategi Badan Pengawasan Mahkamah Agung Tahun 2011.

Surat Keputusan Ketua Mahkamah Agung RI No: 211/KMA/SK/XII/2011.

Wildan Sayuthi Mustofa, Kode Etik Hakim Edisi Kedua, (Jakarta: Kencana, 2013).

https://m.hukumonline.com/berita/baca/it56e2 8289869fd/mau-laporkan-hakim-yuksimak-prosedurnya/

R Mida Hayati, "BAB II Kajian Pustaka (Tanpa Judul)", http://repository.radenintan.ac.id/75/7/ BAB_II.pdf

Said, "Fungsi Pengawasan dalam Islam", http://saidiqbal.blogspot.com/2012/01/fungsipengawasan-dalam-islam.html 